Izvorni članak UDK 111.852:78(045)Hanslick, E. doi: $10.21464 /$ fi36204 Primljeno 23. 3. 2016.

\title{
Tomislav Škrbić
}

Vinogradska 50, HR-44000 Sisak

tomislav.skrbic@gmail.com

\section{Hanslickovo shvaćanje glazbe}

\begin{abstract}
Sažetak
Premda se Hanslickova estetika glazbe pretežito podvodi pod »formalizam《, Hanslickov imanentistički pristup glazbi predstavlja svojevrstan odmak od tzv. estetičkog formalizma. Glazba po Hanslicku ne može ni izazivati ni prikazivati osjećaje, ali može izraziti njihov dinamički aspekt (kretanje). »Glazbeno-duhovni sadržaj«, kao ono imanentno bića glazbe, za Hanslicka je zapravo konkretno jedinstvo melodijskih, harmonijskih i ritmičkih formi (glazbeno lijepo). Razvijanje glazbenog sadržaja odvija se istodobno s razvijanjem glazbenih formi djela. Međutim, Hanslickovo povezivanje glazbeno lijepog s onim formalnim »otvara« prostor za pojavu »moderne« glazbe u kojoj dolazi do krajnjeg razdvoja disonance od

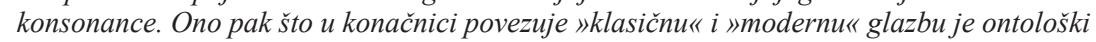
aspekt glazbene umjetnosti, koji se u slučaju »klasične« glazbe oslanja na estetičku moć tonskog izraza, a u »modernoj « je prvenstveno upućen na racionalnost. Pored toga, u»modernoj « je glazbenoj umjetnosti djelo osebujni »egzistencijalni modus « racionaliteta onog glazbenog, dok je u »klasičnoj« tek jedan od modaliteta egzistencije bića glazbe.
\end{abstract}

\section{Ključne riječi}

Eduard Hanslick, estetika glazbe, glazbeno lijepo, formalizam, tonalnost, atonalnost

»Die Musik will nun einmal als Musik aufgefaßt sein und kann nur aus sich selbst verstanden, in sich selbst genossen werden.«

(E. Hanslick)

I.

Namjera nam je da u osnovnim crtama izložimo međuodnos forme i sadržaja u estetici glazbe Eduarda Hanslicka, te potom na osnovi toga pokažemo da se radi o jednoj - po osnovnoj intenciji - ontološkoj, a ne formalističkoj estetici. ${ }^{1}$ Time bi se ujedno trebala pokazati i važnost Hanslickove estetike za fenomen suvremene glazbe.

Tzv. klasični estetički formalizam (npr. J. F. Herbart, R. Zimmermann, a kod nas npr. F. Marković) polazi, naime, od postavke prema kojoj umjetničko djelo nije objektivno, nego subjektivno biće, pa se stoga pojam ljepote

Usp. Ivan Focht, »Hanslickovo zasnivanje estetike muzike«, u: Eduard Hanslick, $O \mathrm{mu}$ zički lijepom, BIGZ, Beograd 1977., str. 24: »Tako nema sumnje da su u Hanslickovom imanentizmu dati brojni začeci i jedne ontološke estetike muzike, veoma upadljiva činjenica koja začudo dosad nije zapažena.« 
u formalističkim estetikama prvenstveno veže uz estetičku predodžbu i sud. Osnovno je svojstvo estetičkog suda, prema formalističkom shvaćanju, svojevrsna istovjetnost subjekta ili estetičke predodžbe predmeta i predikata ili estetske ugode. »Estetska ugoda« je, kako najčešće mniju teoretičari »estetičko-formalističke« provenijencije, psihološki učinak koji nastaje prigodom predočavanja estetskog predmeta. Formalistički stav o umjetnosti svoje najdublje uporište ima u »racionalističkom« vrednovanju osjetilnosti, odnosno pridavanju prvenstva onom razumsko-predodžbenom nad estetskim zrenjem i osjećanjem. Polazeći od određenja prema kojemu je estetički sud sklop predodžbe i ugode, odnosno od uvjerenja o bitnoj uvjetovanosti estetskog iskustva onim formalnim, formalistička estetika navlastite sadržajne aspekte umjetnosti (logički, semantički, etički, psihološki aspekt itd.) »odvaja« od pojma ljepote jer se lijepo, naime, sastoji od predodžbi odnosa elemenata nekog estetskog predmeta. S druge je strane jedna od presudnih razlika - pored formalizmu svojstvenog »zanemarivanja« sadržaja - između »formalističke« i »idealističke« estetike u tome što prva polazi od toga da je umjetnost, zbog presudne ovisnosti o estetskom subjektu, načelno nedostatna spram »objektivne stvarnosti«, dok druga smatra da je umjetnost »niža«, naročito s obzirom na »apsolutnu zbiljnost«.

Imajući, nadalje, u vidu kontekst iz kojega Hanslick pristupa fenomenu glazbe, moglo bi se ustvrditi, parafrazirajući pritom jednu misao Roberta Zimmermanna, da je za Hanslicka estetika glazbe znanost o morfologiji glazbeno lijepog. ${ }^{2}$ Pod glazbeno lijepim Hanslick, u negativnom smislu, podrazumijeva neovisnost glazbe od izvanjskih (neglazbenih) sadržaja, dočim mu pozitivni smisao glazbeno lijepog »leži jedino u tonovima i njihovoj umjetničkoj povezanosti «. ${ }^{3}$ Stoga je upravo Zimmermannova teza o estetici kao morfologiji lijepog ono što, kao vodeća misao, odzvanja u pozadini Hanslickove sintagme o »filozofijskom utemeljenju glazbe«, a čiji se smisao sastoji u tome da se »istraži koje su nužne duhovne odredbe povezane sa svakim od glazbenih elemenata i kako oni međusobno zavise jedan od drugoga« ${ }^{4}$ Međutim, Hanslick se ovakvim shvaćanjem odnosa duhovnih vrednota i glazbenih formi, u određenom pogledu, ujedno i odmiče od racionalističkog formalizma Zimmermannove estetike. Premda se Hanslickovu estetiku »uobičajeno« shvaća kao izraziti formalizam, i to kako sa strane filozofijske estetike tako i sa strane teorije glazbe i muzikologije, ${ }^{5}$ valja naglasiti da iz Hanslickova imanentističko-ontološkog pristupa glazbi, odnosno stava o jedinstvu forme i »duhovnog sadržaja« kao navlastitog karaktera glazbenog bića - gdje je sadržaj uvjetovan glazbenim formama, štoviše proistječe iz forme - slijedi kako Hanslick u konačnici, zapravo, ne pripada među »čiste formaliste«.

Za Hanslicka je prapočelo (Urelement) glazbe sklad, blagozvučje (Wohllaut). Sklad ili harmonija kao metafizičko počelo glazbe nije, iako se može pričinjavati, tek »simetrijsko« sređivanje glazbenog materijala. Sklad je, naime, uvijek nekakva »usklađenost« srodnih ili suprotnih, ali i proturječnih »članova cjeline«. Glazbena harmonija, kao istodobno zvučanje više tonova, počiva na međusobnoj izmjenjivosti konsonanci (npr. prima, oktava) i disonanci (npr. sekunda, septima), odnosno na strukturi akordâ (npr. kvintakord) i njihovih obrata (npr. sekstakord i kvartsekstakord kao obrati kvintakorda). ${ }^{6}$ Tako se, primjerice, smanjeni kvintakord sastoji kako od konsonantnih tako i od disonantnih intervala. Usklađivanje tonskih različitosti je svojevrsno »statičko« očitovanje metafizičkog načela jedinstva u mnoštvu. ${ }^{7}$

Nadalje, prema Hanslicku je bit glazbe - kao fenomena dinamičkog jedinstva u mnoštvu onog zvukovno-tonalnog - ritam, ${ }^{8}$ i to kako u smislu mjere kreta- 
nja s obzirom na jačinu i naglašenost tonova (metrika), tako i u smislu zakonomjernog kretanja s obzirom na trajanje tonova (ritmika). Ritam se, pak, u metafizičkom pogledu može shvatiti i kao mogućnost odmjerenog, uređenog

Usp. Robert Zimmermann, Allgemeine Ästhetik als Formwissenschaft, Wilhelm Braumüller, Wien 1865., str. 30: »Estetika kao čista znanost forme je morfologija lijepog. « Zimmermannov je »sljedbenik« u okvirima hrvatske estetičke tradicije Franjo Marković, pa upravo stoga jedna od njegovih odredb estetike i nalikuje na gore spomenuto Zimmermannovo određenje. Usp. Franjo Marković, Razvoj i sustav obćenite estetike, Naklada Kr. hrv.-slav.-dalm. zemaljske vlade, Zagreb 1903. (pretisak 1981.), str. 23: »Estetika je znanost o formah ljepote, kako je logika znanost o formah istine.« K tomu, i sam Hanslick na jednom mjestu rasprave $O$ glazbeno lijepom napominje da upravo Zimmermann »dosljedno sprovodi formalno načelo u svim umjetnostimak.

Eduard Hanslick, O muzički lijepom, BIGZ, Beograd 1977., str. 83. Hanslickovo djelo $O$ glazbeno lijepom ovdje citiramo prema prijevodu I. Fochta iz 1977. godine, ali uz istodobnu usporedbu s izvornikom.

Ibid., str. 95.

Usp. primjerice F. Marković, Razvoj i sustav obćenite estetike, str. 32: „Naravna poraba glasbe, a napose pieva, kod svih puka od pamtivieka očito pobija onu previše formalističnu nauku Hanslickovu.« Vidi Danko Grlić, Estetika III: Smrt estetskog, Naprijed, Zagreb 1978., str. 324-325. Usp. također Josip Andreis, Povijest glazbe: knjiga 3, Sveučilišna naklada Liber, Zagreb 1989., str. 39: »Hanslick je 1854. izdao glasovitu raspravu $O$ glazbeno lijepom (Vom Musikalisch-Schönen Ein Beitrag zur Revision der Tonkunst) u kojoj je poricao glazbi sposobnost da može izraziti bilo što što se zbiva izvan glazbe. Prema njegovim riječima glazba nije drugo, nego puka 'igra oblika koji se zvučeći kreću'. Taj formalist, koji je olako glazbu uvrstio u kategoriju ornamentiranja i bezidejnih arabesaka, oduzimao je, dakle, glazbenoj umjetnosti veoma snažna sredstva njena djelovanja ne sluteći da će sjajna postignuća ruske, češke, francuske, pa i njemačke glazbe u tijeku slijedećih desetljeća demantirati njegov stav.« $\mathrm{S}$ druge strane postoje i drugačija mnijenja o naravi Hanslickove estetike. Usp. I. Focht, Hanslickovo zasnivanje estetike muzike, str. 21: »Upravo zahvaljujući tome što u samim formama nalazi i sadržaj, Hanslick nije formalist. Formalist bi bio kad bi te forme bile za njega samo sredstvo da se izrazi jedan izvanmuzički predmet.« Usp. također Carl Dahlhaus, Estetika glazbe, AGM, Zagreb
2003., str. 83-84: „Estetiku, kojoj su njezini protivnici prilijepili etiketu 'formalizam', koja je dakle sumnjičena da glazbu unižava do prazne igre koja ništa ne kazuje, trebalo bi, kada bi se pokušalo primjereno je prosuditi, prije označiti kao estetiku 'specifično glazbenog'.«

6

Valja napomenuti da je razvoj glazbene harmonije zapravo dugotrajan proces. Tako je primjerice terca prilično dugo, čak do 12 . st., smatrana disonantnim intervalom. To ukazuje na moment povijesnosti glazbenog fenomena, odnosno na povijesni karakter »suda ukusa«. Usp. E. Hanslick, O muzički lijepom, str. 96: $»$ Nema umjetnosti koja poput glazbe upotrebljava tako ubrzano i tako puno formi. Modulacije, kadence, intervalski pomaci, harmonijski nizovi postaju otrcani već poslije pedeset, pa čak i trideset godina, tako da se njima produhovljeni kompozitor ne može više poslužiti i biva prisiljen stalno iznalaziti nove, čisto glazbene poteze.«

Aristotel na jednom mjestu spisa $O d u s ̌ i$ kaže kako »kretanje nije svojstveno skladu« (De anima 407b34), nego prvenstveno duši. To bi se pak moglo dovesti u svezu upravo s glazbenom harmonijom kao »vertikalnom strukturom« glazbenog djela, odnosno sa »statičkim « karakterom glazbenoga harmonijskog jedinstva. Schelling u Filozofiji umjetnosti harmoniju određuje kao »idealno jedinstvo ili kao »uobličenje mnoštva u jedinstvo«, a to je, također, svojevrsna neizravna potvrda "statičnosti« onog harmonijskog u glazbi. Usp. Friedrich Wilhelm Joseph Schelling, Filozofija umjetnosti, Hrvatska sveučilišna naklada, Zagreb 2008., str. 129: »[§ 82.] Harmonija dolazi, doduše, u različitim značenjima, na primjer ona znači sjedinjenje mnogih $\mathrm{u}$ isti mah izazvanih tonova $\mathrm{u}$ jedan jedini zvuk; ovdje, dakle, biva harmonija shvaćena u najvišoj jednostavnosti u kojoj je na primjer i svojstvo pojedinog zvuka jer u ovom suzvuče ujedno više i od njega različiti tonovi, koji su pak tako točno ujedinjeni da se čini kao da se čuje samo jedan. (...) Iz ovog općeg pojma proizlazi već dovoljno da se harmonija prema ritmu, i u toliko prema melodiji, jer melodija nije drugo doli integrirani ritam, da se, kažem, harmonija spram melodije odnosi opet kao idealno jedinstvo spram realnoga ili kao uobličenje mnoštva u jedinstvo spram suprotnog jedinstva u mnoštvo, što se imalo dokazati.«

Usp. F. W. J. Schelling, Filozofija umjetnosti, str. 125: »Dodatak [uz $\S 79$, op. a.]. Ritam je 
kretanja naspram mogućnosti »kaotičnog gibanja«. ${ }^{9}$ Prisutnost klasičnih metafizičkih (ontologijskih) određenja u teoriji glazbe (npr. harmonija, ritam, jedinstvo), tj. u samome fenomenu glazbe, ukazuje i na osebujnu svezu glazbe s filozofijom. Filozofija se spram navedenih određenja odnosi tako što ih izričito poima, čineći ih pritom navlastitim sadržajem. S druge je strane sadržaj istinske glazbe, a to je, prema Hanslicku, instrumentalna glazba, nepojmovan i nepredmetan (neintencionalan), odnosno »čisto glazben« (glazbeno lijepo određenog djela). Stoga bi se, polazeći od Hanslicka, moglo reći da je temeljna razlika između filozofije i glazbe u tome što filozofija u konačnici svoj sadržaj »zadobiva« na posredan, teoretski način, tj. putem pojmovnog mišljenja, a glazba na neposredan, estetsko-poietički način. Glazbeni sadržaj izravno proizlazi iz glazbeno-formalnih odnosa koji se uspostavljaju između tonova. Ono glazbeno-formalno je, kao »unutrašnja struktura« ili »pritajena mogućnost«, prisutno već i u samim tonovima. ${ }^{10}$ Tako je, primjerice, $\mathrm{u} » k \mathrm{kla}-$ sičnoj« glazbi strukturiranje tonskoga materijala u određeni glazbeni izraz ujedno i očitovanje »glazbeno-emotivnog« sadržaja, dok je, nasuprot tome, u »modernoj«, »besadržajnoj « glazbi strukturiranje tonskog materijala zapravo sredstvo »izraza « racionalnosti glazbe, ali također i »apstraktno-matematičke» naravi tonske materije. Drugim riječima, »element« filozofije je pojmovno, posredujuće mišljenje jer filozofija svoj sadržaj zahvaća time što ga pretvara u pojam ili »intencionalni misaoni predmet«; a u glazbi je, gledano načelno, sadržaj neposredno prisutan u tonovima, tj. u tonalnim odnosima.

Hanslick tonalne odnose shvaća, naravno, pod vidom tonaliteta kao načela sređivanja tonskih nizova u određene durske i molske ljestvice $\mathrm{s}$ harmonijskim središtem (tonika ili prvi, tj. temeljni ton oktave). Tonalitet, kao načelo sređivanja tonskih nizova, vladao je europskom glazbom od 17. do početka 20. stoljeća, tj. do pojave »moderne«, atonalne glazbe koja odustaje od tonaliteta te time i od melodije kao »osnovnog oblika glazbene ljepote«. Ovaj je proces unutar glazbene umjetnosti, a s obzirom na mogući metafizičko-teološki identitet glazbe, analogan »gubljenju« metafizičkog središta, odnosno »rastvaranju « onto-teo-loškog ustroja metafizike.

Glazbeni sadržaj, prema Hanslicku, dakle, proizlazi iz formi, pa zato i nije "predmetan«, nego je učinak »oblikovanja tonova kao slobodnog duhovnog stvaranja «. ${ }^{11}$ Drugačije kazano, neposredno proizlaženje sadržaja iz forme implicira kako »nepredmetni« karakter glazbenog bića tako i prvenstvo ontološkog momenta u samoj glazbenoj umjetnosti.

Iako Hanslick izričito ne razlučuje metafizičke od glazbeno-estetičkih aspekata harmonije i ritma, on ih ipak neizričito razlikuje - a to se također može uzeti kao formalistički element njegove estetike - na pozadini razlikovanja onog prirodnog i onog specifično glazbenog. U prirodi, osim što ne postoji melodija kao specifično ljudska tvorevina, ne postoje niti harmonija niti ritam u strogo »glazbenom smislu«, nego kao »veličanstvena harmonija svih pojava «, ${ }^{12}$ odnosno kao $» j e d i n i$ glazbeni praelement u prirodi $\ll .{ }^{13}$ Za Hanslicka je presudna razlika između prirodne i glazbeno-umjetničke harmonije i ritma u tome što

»... u glazbi, naime, ne postoji izolirani ritam kao takav, nego samo melodija i harmonija koja se ritmički očituje ${ }^{14}$

Melodija, ritam i harmonija su, uvjetno kazano, osnovne glazbene forme.

Kao što smo prethodno napomenuli, Hanslickovo ustrajavanje na glazbenom sadržaju predstavlja odmak od čistoga estetičkog formalizma (J. F. Herbart, 
R. Zimmermann), ali i od idealističkog pristupa umjetnosti (npr. Hegel). U takvom kontekstu posebno je zanimljiva idealistička, primjerice Hegelova, koncepcija sadržaja u glazbi. Polazeći od toga da je sadržaj umjetnosti apsolutna ideja, a svrha »osjetilno prikazivanje apsoluta«, Hegel ustvrđuje da glazba postaje istinska umjetnost tek »kada se u osjetilnom elementu tonova i njihovih različitih oblikovanja duhovno izrazi na primjeren način «. ${ }^{15}$ Sukladno takvom shvaćanju glazbene umjetnosti, za Hegela je jedini pravi (istinski) zadatak glazbe u tome da dani sadržaj prikaže »na onaj način na koji on živi i nastaje u oblasti subjektivne unutrašnjosti«. ${ }^{16}$ Unutar »subjektivne unutrašnjosti« upravo je osjećanje - kao apstraktna unutrašnjost - ono "područje« subjektivnosti s kojim je, prema Hegelu, glazba nužno povezana. Glazba, zapravo, i nije drugo doli izraz »posebnih osjećaja (radosti, straha, boli, ljubavi itd.), dok je sámo osjećanje tek nešto što »prekriva« zahvaćeni sadržaj. Drugim riječima, zadatak je glazbe da kao »izraz svih posebnih osjećaja« u konačnici izazove »duhovno osjećanje [geistvolle Empfindung]《 nekoga određenog opažajnog, tj. predodžbeno-misaonog, sadržaja. Na pozadini uvida u apstraktnu narav osjećaja i osjećanja, odnosno poimanja glazbe

glazba u glazbi. - Jer posebnost glazbe zasnovana je upravo na tome da je ona uobličenje jedinstva u mnoštvo. Budući da prema $\S 79$ ritam nije ništa drugo nego ovo uobličenje samo u glazbi, on je stoga glazba u glazbi.«

9

Usp. E. Hanslick, $O$ muzički lijepom, str. 83. »Praelement glazbe je sklad, njena bît ritam. Ritam u velikom, kao skladnost neke simetrične građevine, i ritam u malom, kao izmjenično zakonito kretanje pojedinih članova u taktu.« $\mathrm{O}$ »neglazbenom« značenju ritma, u rasponu od »grčke« do »suvremene« filozofije, postoje brojne misli koje ovdje ne možemo navoditi. Stoga tek kao primjer izdvajamo dva mnijenja iz naše recentne filozofijske estetike. Vidi Milan Galović, Doba estetike, Izdanja Antibarbarus, Hrvatsko društvo pisaca, Zagreb 2011., str. 81: »Ritam uključuje vrijeme, on je ponavljanje u nekom vremenskom razmaku (ponavljanje naglaska $u$ pjesmi, tona, nekog obrasca, pokreta u plesu itd.). No čovjek je uočavao ritam i kao jedan vid reda u cijelom svijetu, neki ga vide kao 'prafenomen života' (srce, disanje, spavanje-budnost, odmor-rad, dan-noć, mjeseci, godine, godišnja doba...).«Vidi također Predrag Finci, Estetska terminologija, Izdanja Antibarbarus, Zagreb 2014., str. 165-166: »Ritam je biće samo. (...) O ritmu se govori na različite načine, od idealističke vjere u kozmički ritam kao ishodište Bitka preko kazivanja o životnom ritmu, o ritmu prirode i ritmu urbanih sredina do neomarksističkih rasprava o utjecaju ritma proizvodnje i tržišta na ljudsku egzistenciju.«

10

Usp. E. Hanslick, O muzički lijepom, str. 8384: »Materijal od kojega kompozitor stvara i čije se bogatstvo ni ne može zamisliti odveć rasipničkim, to su svi tonovi sa svojom pritajenom mogućnošću stvaranja različitih melodija, harmonija i ritmizacija.« Ovdje valja napomenuti da Hanslick, usprkos tome što zastupa stav o formi kao onom glazbeno lijepom, a to je sukladno osnovnoj intenciji estetičkog formalizma, u konačnici ipak ne izjednačava formalno-estetski i umjetnički moment glazbe.

11

E. Hanslick, O muzički lijepom, str. 177. Ovdje, naime, treba napomenuti da misao o proizlaženju sadržaja iz forme prožima, kako primjerice primjećuje V. Sutlić, i Hegelovu Znanost logike, pa bi se moglo reći da Hanslick na osebujan način »nasljeduje« Hegelovu dijalektiku pojma (tzv. samoeksplikacija pojma). Pritom moramo pretpostaviti da sam Hanslick, zapravo, nije svjestan vlastitog »nasljedovanja« Hegelove »dijalektičke metode«. Usp. Vanja Sutlić, Predavanja o Hegelu (1968-1969), Institut za filozofiju, Zagreb 2016., str. 25: »Zbivanje kojim sadržaj nastaje u samorazvitku forme pravi je predmet Hegelove logike. Logika dakle nije s jedne strane sadržaj ili materija, a s druge forma kao pretpostavka logike, nego je logika samokonstituiranje sadržaja iz unutarnje raščlambe forme.«

12

E. Hanslick, ibid., str. 150.

13

Ibid., str. 152.

14

Ibid., str. 151-152.

15

Georg Wilhelm Friedrich Hegel, Werke, Bd. 15: Vorlesungen über die Ästhetik III, Suhrkamp Verlag, Frankfurt am Main 1970., str. 149.

16

Ibid 
kao »suprotnosti osjeta i unutrašnjosti«, Hegel izvodi zaključak da je glazba po sebi »besadržajna«. ${ }^{17}$

Međutim, upravo je određenje glazbe kao izraza osjećaja ono što je prema Hanslicku krajnje upitno. Štoviše, za Hanslicka u strogome smislu:

»Prikazivanje određenog osjećaja ili afekta nije u vlastitoj moći glazbe. $\ll^{18}$

Jasno je da Hanslick pritom misli na instrumentalnu glazbu kao jedinu »čistu, apsolutnu umjetnost tonova«. Kao što je za Hegela sadržaj u glazbi jedan »izvanjski moment «, tj. ono spram čega glazba intendira, tako je za Hanslicka »glazbeno-duhovni sadržaj« nešto imanentno u smislu da proizlazi iz onog formalnog u biću glazbe. S druge strane, glazba ipak nešto »prikazuje«, a to je moment kretanja u osjećajima, odnosno dinamički aspekt osjećaja. Hanslick na jednom mjestu ustvrđuje da glazba »može reproducirati kretanje jednog fizikalnog procesa u njegovim momentima: brzo, lagano, slabo, ubrzano, usporeno« ${ }^{19}$ ali »kretanje je samo jedno svojstvo, moment osjećaja, ne sam osjećaj « ${ }^{20} \mathrm{~S}$ obzirom na to da se određeni osjećaj (ljubav, nada, bijes, čežnja itd.) ne može izdvojiti iz cjeline onog duševnog, a da se pritom ne svede na puki fenomen ili osjet ugode i neugode, proizlazi da osjećaji imaju ne samo »fiziološko-patološku« nego i »predodžbeno-misaonu« dimenziju. Drugim riječima, iako glazba ne može prikazati niti predmet konkretnog osjećaja niti sam taj osjećaj, ona može »izraziti« kretanja koja se mogu pojaviti uz osjećaj (silovitost, sputanost, lepršavost, poletnost, polaganost itd.). ${ }^{21}$ Stoga se prema Hanslicku »određenost « osjećaja u konačnici i temelji na njihovoj »pojmovnoj jezgri« koju glazba ne može izraziti. ${ }^{22}$

Time pojam »duhovnog sadržaja« zadobiva dva aspekta od kojih je prvi idealistički, pojmovni i intencionalni, a drugi formalni, nepojmovni i imanentni, tj. »specifično-glazbeni«. Duhovni je sadržaj za Hanslicka konkretno jedinstvo melodijskih, harmonijskih i ritmičkih formi, odnosno duhovni sadržaj »pripada jedino udruženosti svih ovih članova «. ${ }^{23}$ Osim toga, duhovni sadržaj je, kao proizvod »slobodnoga fantazijskog stvaranja«, ujedno i nosilac individualiteta glazbenog djela. Tako je, primjerice, specifičnost Bachovih djela jedan osebujni metafizički sadržaj koji »proizlazi« iz uporabe kontrapunktne polifonijske tehnike.

Pored toga što kritici podvrgava idealističko shvaćanje pojma umjetničkog sadržaja u glazbi, Hanslick, također, ne prihvaća u potpunosti niti formalističko shvaćanje glazbeno lijepog. Glazbeno lijepo nije isključivo "puko akustički« ili proporcijsko-simetrijski sklad tonova jer upravo duhovni sadržaj »stoji u najužoj vezi s tonskim formama«, te stoga u konačnici i »najneukusnija tema može biti potpuno simetrično izgrađena «. ${ }^{24}$

Polazeći, naime, od teze o racionalitetu estetičkog suđenja (ars pulchre cogitandi), zastupnici estetičkog formalizma nastoje pokazati kako su upravo matematičko-geometrijske zakonitosti, kao konstitutivna načela glazbenoga estetskog predmeta, ono što u subjektu izaziva estetičku ugodu. Estetički formalizam zato i poseže za fiziološko-psihološkim i akustičkim istraživanjima tonskog materijala (npr. H. Helmholtz, A. Zeising) kako bi se ustanovilo i potvrdilo da iz materijalno-fizikalnog elementa glazbe proizlazi i njezina estetsko-umjetnička vrijednost.

No kao što je simetrija »samo jedan relativan pojam «, ${ }^{25}$ tako i u nekom glazbenom djelu »ništa nije matematički izračunato « ${ }^{26} \mathrm{~S}$ obzirom na odnos fizikalnog aspekta glazbe i glazbeno lijepog - sukladno implicitnom zahtjevu za filozofijskim utemeljenjem glazbe - Hanslick konstatira sljedeće:

»Ono što je za nas najznačajnije jest i ostaje neobjašnjeno: živčani proces, preko kojega se percepcija tona pretvara u emociju, u duševno raspoloženje. $^{27}$ 
Drugim riječima, iz Hanslickova pristupa problemu izražajne moći glazbe, kao središnjeg problema estetike glazbe, proizlazi da je tonski izraz već i u svojem »puko« receptivnom aspektu načelno otvoren, neriješen.

Osim mogućnosti »prikazivanja« onog dinamičkog u osjećajima, glazba, prema Hanslicku, raspolaže još samo simbolikom kao sredstvom prikazivanja osjećaja i duševno-emotivnih stanja. Tonovi, naime, mogu imati i simboličko značenje, pa tako u receptivnom estetskom subjektu primjerice G-dur može izazvati vedrinu, a As-dur sanjalačko raspoloženje. No simboličko tumačenje tonova i tonskih nizova, načelno gledano, nije estetsko jer »ne prikazuje sadržaj neposredno, nego ostaje jedna, od toga sadržaja bitno različita forma«. ${ }^{28}$ Simboličko tumačenje glazbe presudno je uvjetovano »subjektivnim doživljajem《 svakoga pojedinog tona i akorda, međutim »u svojoj umjetničkoj primjeni ovi elementi (tonovi, boje) slušaju sasvim druge zakone, nemaju djelovanje kao kad se javljaju izolirano«. ${ }^{29}$ Stoga se u konačnici »ne može ni za jedan akord reći da po sebi prikazuje određeni osjećaj, a još manje u kontekstu umjetničkog djela«. ${ }^{30}$

17

Usp. ibid., str. 136: »Ta nepredmetna unutrašnjost, s obzirom na sadržaj i način izražavanja, sačinjava ono formalno glazbe. Međutim, i glazba ustvari ima sadržaj, ali ne u smislu likovnih umjetnosti i poezije; jer njoj nedostaje objektivno samooblikovanje bilo $\mathrm{u}$ formi zbiljskih izvanjskih pojava ili pak u objektivnosti duhovnih zorova i predodžbi.«

18

E. Hanslick, O muzički lijepom, str. 56.

19

Ibid., str. 60 .

20

Ibid.

21

Usp. ibid., str. 60: »Obično se misli da je prikazivačka moć glazbe dovoljno ograničena ako se tvrdi da ona ne može izraziti predmet nekog osjećaja, ali može osjećaj sam, npr. ne objekt određene ljubavi, nego 'ljubav' kao takvu. Ustvari, ona to podjednako nije u stanju. Ne ljubav, nego samo neko kretanje ona može oslikati, kretanje koje se javlja uz ljubav, ali i uz neki drugi afekt, pa ipak uvijek predstavlja nebitne crte njegovog karaktera.«

22

Usp. ibid., str. 58: »Jedan određeni osjećaj (strast, afekt) nikad ne egzistira kao takav bez stvarnog historijskog sadržaja koji se može jedino i izložiti u pojmovima. Glazba kao 'neodređeni jezik' ne može, kao što se i priznaje, reproducirati pojmove - nije li onda psihološki uzevši neizbježan zaključak da ona ne može izraziti ni određene osjećaje?«

23

Ibid., str. 95.
24

Ibid., str. 103. Tako primjerice i F. Marković smatra da tek jedinstvo simetrije i proporcije predstavlja puni pojam tzv. forme sklada (harmonije). To je onda i razlog zbog kojega je Marković skloniji Zeisingovoj teoriji glazbene harmonije naspram Helmholtzova i Zimmermannova shvaćanja harmonije. Usp. F. Marković, Razvoj i sustav obćenite estetike, str. 339: »Po Helmholtzu i Zimmermannu stoji sklad zvukova u pretežnoj istovetnosti njihovih sastavnih česti, a nesklad zvukova potječe od pretežne neistovetnosti njihovih sastavina. Na drugi način tumači zvučni sklad Zeising; on hoće dokazati, da su najskladnija ona sazvučja, koja nastaju od glasova sumjernih i razmjernih. Zeising dakle misli, da se isti estetički zakon spojene sumjernosti i razmjernosti, koji je on dokazao za plastičnu $\mathrm{i}$ arhitektonsku ljepotu, izvršuje takodjer u muzikalnoj ljepoti.«

25

E. Hanslick, O muzički lijepom, str. 103.

26

Ibid., str. 104.

27

Ibid., str. 124. Gornja bi se Hanslickova konstatacija mogla oblikovati u pitanje koje, zapravo, pripada području filozofije, tj. gnoseologije, umjetnosti: Kako, na koji način osjet (fizikalni osjećaj) postaje, prelazi u osjećanje (estetsko-emotivni osjećaj)?

28

Ibid., str. 62.

29

Ibid.

30

Ibid. 
Time dolazimo i do Hanslickove centralne odredbe sadržaja glazbe koja glasi:

»Sadržaj glazbe su forme koje se kreću zvučeći (tako što zvuče). «31

Iz potrebe da navedenu odredbu dovede do što je moguće veće pojmovne jasnoće, proizlazi nadalje i Hanslickova »nesretna« analogija između lijepih glazbenih formi i arabeske, koja je u kasnijim tumačenjima postala nezaobilazan primjer za potvrđivanje formalističke naravi njegove estetike. Za nas se pak problem, već i gramatičko-semantički gledano, sastoji u tome što se njemačko bewegt obično prevodi s 'pokretno' ili 'pokrenuto', ali ustvari može značiti 'ono koje se kreće', slično kao u grčkom to kinoumenon. Glazbene se forme, dakle, mogu shvatiti ili kao idealno-statične (apstraktno-matematičke) strukture, koje tek tonovi »stavljaju « u kretanje, ili kao idealno dane mogućnosti bića glazbe, koje su kao takve u neprestanom kretanju. Duhu Hanslickove estetike nesumnjivo odgovara drugonavedeni smisao jer osim uvođenja sintagme »živa arabeska« - čime se implicira da je kretanje imanentno glazbeno lijepom - Hanslick razliku između »tonske« i slikovne arabeske vidi i u tome što se tonska arabeska »našem uhu iskazuje kao neposredna emanacija jednog umjetničkog stvaralačkog duha «, ${ }^{32}$ odnosno glazba je u razlici spram vizualne arabeske »jedna slika, ali takva da se njen predmet ne može riječima izraziti ni našim pojmovima podvrgnuti«. ${ }^{33} \mathrm{Iz}$ toga, također, proizlazi i presudna važnost osjetilnosti, slušanja i sluha - naspram osjećanja kao patološkoga estetičkog stanja - za izgradnju (glazbene) umjetničke fantazije u estetskom subjektu. ${ }^{34}$

Može se stoga reći da je ono glazbeno zapravo »dinamička moć« kretanja, kao ritmičko nastajanje i nestajanje tonova, koje se ne da do kraja objasniti matematičkim zakonitostima. Glazbeno lijepo nadilazi ograničenja onog matematičkog jer se ne da svesti tek na odraz ili izraz matematičko-glazbenih pravilnosti.

Gledano, pak, iz pozicije estetske predmetnosti, produktivnost umjetničke fantazije uvjet je mogućnosti glazbe uopće, dočim je samo komponiranje zapravo »zahvaćanje « i »logičko izvođenje « glazbenih ideja iz sfere idealnih mogućnosti, u kojoj je biće glazbe noetički zadano, u zvukovnu pojavnost. ${ }^{35}$ Estetički doživljaj glazbe učinak je, dakle, fantazije kao »djelatnosti čistog zrenja«, tj. »zrenja s razumom«, koje i nije drugo doli »pažljivo«, odnosno sukcesivno praćenje tonskih formi. Hanslickovo inzistiranje na izravnoj povezanosti osjetilnosti i fantazije, koje je bitno uvjetovano dinamičkim karakterom glazbe, ukazuje i na to da se sadržajni aspekt glazbenog izraza nalazi u konkretnoj tonskoj tvorevini (tonskim formama), a ne tek u sferi »osjećanja« ili »ideja«. Isto tako i neizravno pozivanje na sferu idealnih glazbenih mogućnosti samo nam potvrđuje da je, s obzirom na »glazbeno biće«, Hanslickova osnovna intencija ontološka. Drugim riječima:

»Hanslickovo učenje daje klasičan primjer kako estetički objektivizam mora dovesti do ontologizma. $\ll^{36}$

Imajući u vidu da tonovi Hanslicku predstavljaju »neprevodivi prajezik«, valja još jednom ponoviti da glazba, osim tonskih formi, nema nikakav drugi (predmetni) sadržaj. Hanslick razlučuje glazbu od jezika time što glazbenotonskom materijalu pridaje poseban ontološki status, tj. ton shvaća kao $s a-$ mosvrhu, dok mu tonovi u okviru jezika imaju jedino smisao da kao znak ili sredstvo prikazuju izvantonski sadržaj. ${ }^{37}$ Glazba je zato neprikazivačka umjetnost. U glazbi su, dakle, »sadržaj i forma, građa i oblikovanje, lik i ideja stopljeni u jedno nerazlučivo, neraskidivo jedinstvo «. ${ }^{38}$ Smisao nerazlučivog jedinstva forme i sadržaja, kao bitnog obilježja glazbeno lijepog, sažima se 
u Hanslickovu poistovjećivanju glazbenih ideja s pojmom glazbenog sadržaja. Točnije kazano, glazbene su ideje, prema Hanslicku, istovjetne s formama, odnosno u konačnici s glazbenim motivima (najmanje kompozicijsko jedinstvo melodijsko-ritmičkog kretanja) ili temama (cjelovita melodijskoritmičko-harmonijska glazbena »misao«). ${ }^{39}$ Tonskim se materijalom zapravo »izražavaju glazbene ideje«, koje se pak očituju i kao »forme pokrenute tonovima«, odnosno kao »teme tonskog djela«. Ideje, forme ili teme, tj. motivi, mogli bi se stoga shvatiti i kao osebujne »modifikacije« glazbenog sadržaja. Izravni je učinak uspostave ili razvijanja formi konkretnoga glazbenog djela dakle sadržaj, i to shvaćen u smislu duha »koji se iznutra samooblikuje«. ${ }^{40}$ Kao što nije mogao prihvatiti Hegelovu tezu o »besadržajnosti« glazbe, tako, s druge strane, Hanslick zapravo »usvaja« Hegelovu misao o ideji kao sadržaju umjetnosti, tj. o lijepom kao »osjetilnom pojavljivanju ideje $\ll,{ }^{41}$ ali ideja ili idealni sadržaj je u slučaju glazbe isključivo ono tonsko, a ne »pojmovno koje bi tek trebalo prevesti na tonove $\ll{ }^{42}$ Može se reći da je Hanslickova recepcija Hegelova pojma »ideje«, koja se odvijala preko F. Vischera (vidjeti bilješku 8 teksta prijevoda $O$ glazbeno lijepom), prvenstveno usmjerena na pojavljivanje (Erscheinen) kao »realni« aspekt objektivacije ideje ${ }^{43}$ odnosno na mo-

31

Eduard Hanslick, Vom Musikalisch-Schönen. Ein Beitrag zur Revision der Tonkunst, Breitkopf \& Härtel, Wiesbaden 1989., str. 59.

32

E. Hanslick, O muzički lijepom, str. 85.

33

Ibid., str. 87.

34

Usp. ibid., str. 86: »Ali fantazija, koja se organizira na slušnim osjetima i kojoj osjetilo predstavlja sasvim nešto drugo nego puki lijevak na površini pojava, uživa u svjesnoj osjetilnosti zvučnih figura, tonova u njihovoj samonadgradnji, i živi slobodno i neposredno dok ih zre.»

35

Usp. ibid., str. 89: »Ona ključna točka od koje polazi svo daljnje stvaranje kompozicije ne nalazi se u propisu da se određena strast glazbenim putem oslika, nego u otkriću određene melodije. Zahvaljujući onoj primitivnoj, tajanstvenoj moći, u čiju radionicu ljudsko oko nikad nije prodrlo i neće prodrijeti, zazvuči $\mathrm{u}$ kompozitorovom duhu jedna tema, jedan motiv.«

36

I. Focht, Hanslickovo zasnivanje estetike muzike, str. 27.

37

Usp. E. Hanslick, O muzički lijepom, str. 106: »Samostalna ljepota tonskih formi na strani glazbe i apsolutna prevlast misli nad tonom kao pukim izražajnim sredstvom na strani jezika toliko su isključivo suprotstavljeni da miješanje njihovih dvaju principa predstavlja logičku nemogućnost.«
38

Ibid., str. 171. Usp. također Josip Andreis, Vječni Orfej: uvod u muzičku umjetnost, Školska knjiga, Zagreb 1968., str. 74: »Odavno je utvrđeno da su sadržaj i forma nedjeljivi, da se prožimaju u dijalektičkom jedinstvu da izviru jedan iz drugoga i prelaze jedan $u$ drugi. Forma čini sadržaj preglednim, ona ga vodi i čuva od zasjeda kaotičnosti i amorfnosti. Sadržaj preobražava formu ulijevajući život u apstraktnost sheme i golog kalupa.«

39

Usp. E. Hanslick, O muzički lijepom, str. 171 »Poslušajmo bilo koju glavnu temu, npr. iz Beethovenove Simfonije u B-duru. Što je njen sadržaj? Sto njena forma? Gdje ona počinje, a gdje on prestaje?« Vidi također C. Dahlhaus, Estetika glazbe, str. 80: »U njegovoj estetici [Hanslickovoj, op. a.] 'forma' je analogna 'glazbenoj ideji' (...)«

40

E. Hanslick, ibid., str. 87. Usp. E. Hanslick, Vom Musikalisch-Schönen, str. 63: „Forme koje se oblikuju od tonova nisu prazne, nego ispunjene; nisu puki obrisi nekog vakuuma, nego duh koji se pokazuje time što se iznutra oblikuje.«

41

Usp. E. Hanslick, O muzički lijepom, str. 60 »Po sebi se razumije da su samo ideje, tj. oživljeni pojmovi, sadržaj umjetničkog otjelovljenja.«

42

Ibid., str. 89.

43

Usp. ibid., str. 89: »Cilj je svake umjetnosti da neku ideju, oživotvorenu u umjetnikovoj fantaziji, proiznese u izvanjsku pojavnost.« 
ment »egzistencije ideje« kao istinske pojave. ${ }^{44}$ Proces razvijanja glazbenog sadržaja, prema Hanslicku, je simultan s razvijanjem glazbenih formi djela, ${ }^{45}$ te stoga nastajanje glazbenog djela i nalikuje organskim procesima u smislu neposredne podvrgnutosti »formalnim zakonima ljepote $« .{ }^{46} \mathrm{Za}$ Hanslicka je, dakle, već sama egzistencija glazbenih ideja potvrda njihove istinitosti, dok se prema Hegelu istinita, zbiljska egzistencija razlikuje od puke egzistencije upravo po tome što je ona egzistencija ideje. Zbiljnost se, prema Hegelu, sastoji u sukladnosti pojma i realiteta.

Glazbena je tema, zapravo, istinski (pra)sadržaj glazbenog djela. Tema kao »aksiom za sebe«, odnosno kao »glazbeni mikrokozmos« koji u sebi sadržava sve svoje mogućnosti, i samog kompozitora »tjera« na daljnje razvijanje $i$ oblikovanje upravo tih mogućnosti. ${ }^{47}$ Glazbena tema je, kao »nerazdvojivo« središte djela, istodobno objektivna (dolazi iz sfere idealnih mogućnosti) i subjektivna, odnosno tema je heteronomna jer iz objektivne idealnosti »upada« u subjektivnu svijest (unutrašnji sluh kompozitora). ${ }^{48}$ Glazbeno je biće, stoga, povezano s modalitetom slučajnosti i to zbog upućenosti na subjektivnu svijest kompozitora u smislu otkrića »određene teme«, ali uostalom i zbog odnosa sa slušateljima u slušanju i pamćenju. Međutim, preko produktivnoga estetskog akta ono je povezano i s modalitetom nužnosti jer oblikovanje djela nije samovoljna improvizacija, nego razvijanje unutrašnjih mogućnosti same teme. Tako i Hanslickovo određenje tzv. »slobodnog preludiranja« kao nesadržajnog proizlazi, naravno, iz prethodno navedenih određenja komponiranja, pa se stoga »udjelovljenje« glazbene teme istinski odvija jedino na način imanentne nužnosti. ${ }^{49}$ Objektivnost bića glazbe i subjektivnost produktivne umjetničke fantazije »realno « se spajaju - u razlici spram partiture kao idealnog sklopa - u izvedbi konkretnoga glazbenog djela. »Otkriće teme« i »specifičan način « njezina umjetničkog oblikovanja pretpostavke su za autentičnost glazbenog djela, odnosno time se u djelo utiskuje »biljeg individualiteta «. ${ }^{50}$

Iz svega navedenog proizlazi da glazba u konačnici posjeduje i moć prisile jer "samo nešto objektivno u lijepom vrši prisilu «. ${ }^{51}$ Moglo bi se čak reći da je »moć prisile« u slučaju glazbe posebno naglašena i to upravo zbog specifičnoga estetskog djelovanja glazbe koje je, pak, bitno uvjetovano kako samim osjetilnim momentom (sluh i ono akustičko), tako i načelnom odsutnošću onog pojmovnog u glazbenom biću. Međutim, moć prisile izvorno ipak proizlazi iz objektivnosti bića glazbe, odnosno iz objektivnosti samoga glazbenog djela. Objektivnost bića glazbe kozmičkog je podrijetla (musica mundana), ${ }^{52}$ pa glazba u čovjeku zato i izaziva estetske učinke. Estetsko djelovanje glazbe posljedica je ontološke analognosti kozmosa i čovjeka.

Hanslickov objektivistički i imanentistički pristup fenomenu glazbe, iako uvjetovan klasičnim tonalnim sustavom, »završava« u ontologizmu, odnosno u naglašavanju prvenstva ontološkog aspekta glazbene umjetnosti ${ }^{53}$ nad gnoseološkim aspektom (izražavanje ili prikazivanje osjećaja). Ontološkim pristupom glazbi ujedno se i čuva pojam »istinskog«, duhovno-metafizičkog glazbenog sadržaja. ${ }^{54}$

\section{II.}

Hanslickov estetički objektivizam polazi, dakle, od glazbenoga umjetničkog djela, odnosno od specifičnih formalnih osobina djela, pa se time važnost ili, bolje kazano, karakter umjetnika postavlja u »drugi plan «. ${ }^{55}$ Umjetnik je stoga u konačnici tek »prenositelj« glazbe iz njezine objektivne idealnosti u stvarnost. Shodno tome ni navlastito formalna narav glazbeno lijepog nije 
ograničena glazbeno-stilskim razdobljima, nego glazbeno lijepo, prema Hanslicku, vrijedi kako za klasičnu, tako i za romantičku glazbenu vrstu. Drugim riječima, glazbeno lijepo vrijedi »i u jednom i u drugom pravcu, vlada Bachom podjednako kao i Beethovenovom, Mozartom kao i Schumannom «. ${ }^{56}$

44

Usp. ibid., str. 84: »Međutim, neka glazbena ideja, ako je dovedena potpuno do pojavnosti, već je samostalno lijepo, već je vlastiti cilj, a nipošto tek sredstvo ili materijal za prikazivanje osjećanja i misli.« Vidi Georg Wilhelm Friedrich Hegel, Predavanja iz estetike I, Demetra, Zagreb 2011., str. 97-98: »Sve što egzistira istina je samo po tomu što je egzistencija ideje. Ideja je, naime, jedino istinski zbiljsko. Ono što se pojavljuje nije istinito već samim tim što ima izvanjski i unutrašnji opstanak te je općenito realitet, nego jedino time da realitet odgovara pojmu. Tek onda opstanak ima zbiljskost $\mathrm{i}$ istinu.«

\section{5}

Usp. E. Hanslick, O muzički lijepom, str. 90: »Ali glazbeni šampanjac ima tu osobinu da raste zajedno s bocom.«

46

Usp. ibid., str. 173: „Budući da kompozicija slijedi formalne zakone ljepote, njen tok nije improviziran kao proizvoljno neplansko vrludanje, nego se razvija organski, pregledno i postupno kao bogat cvat iz jednog pupoljka.«

47

Usp. ibid., str. 175: »Ali, ono što u temi (otvoreno ili skriveno) ne leži, ne može se ni kasnije organski razviti, i možda manje u Beethovenovom umijeću provedbe nego $u$ simfonijskoj snazi i plodnosti tema leži uzrok što naše doba više ne otkriva njegova orkestralna djela.« Hanslickova misao o temi kao " glazbenom mikrokozmosu« može se u formalnom smislu povezati s Hegelovom misli o razvijanju pojma kao dijalektičkom kretanju kroz opće, posebno i pojedinačno jer razvijanje glazbene teme i nije drugo doli razvijanje njezinih unutrašnjih mogućnosti. Drugačije kazano, razvijanje teme je umjetničko prevođenje idealnih glazbenih mogućnosti u glazbenu realnost.

48

Vidi bilj. 35.

49

Usp. E. Hanslick, O muzički lijepom, str. 97: »Fantazija produhovljenog umjetnika otkrit će u prikriveno-praizvornim odnosima glazbenih elemenata i njihovim bezbrojnim mogućim kombinacijama one najfinije, najskrovitije, oblikovat će tonske forme za koje bi se reklo da su pronađene na osnovi najslobodnije proizvoljnosti i ipak ujedno povezane nevidljivim, finim nitima s nužnošću.«
50

Hanslick, naime, smatra da upravo način na koje je neko glazbeno djelo oblikovano, tj. specifična formacija djela, predstavlja izraz njegova individualiteta. Glazbeno lijepo, kao konkretni sklop forma-sadržaj, nije izraz »apstraktnog subjektiviteta« ili »nepredmetne unutrašnjosti« (Hegel), nego »lijepog oblikovanja tonova«. Drugačije kazano, Hanslick se ne slaže s Hegelovim stavom prema kojem glazbi, zapravo, nedostaje »objektivna samooblikovanost« jer Hanslick objektivitet glazbenog djela izvodi iz glazbenih formi, a ne iz mogućnosti izražavanja osjećaja. Stoga umjetnički oblikovano glazbeno djelo nije nimalo manje »objektivno« od djela drugih umjetnosti. Usp. E. Hanslick, O muzički lijepom, str. 176: »Dok stoga ne možemo dijeliti Hegelovo shvaćanje o besadržajnosti glazbe, čini nam se još gora zabluda što on ovoj umjetnosti pripisuje samo izraz 'unutrašnjosti bez individualiteta'. Pa čak is Hegelovog muzičkog stajališta, koje previđa kompozitorovu bitno oblikotvornu, objektivnu djelatnost, shvaćajući glazbu čisto kao slobodno očitovanje subjektiviteta, ne proizlazi da je on 'bez individualiteta', budući da se duh koji subjektivno proizvodi bitstveno manifestira kao individualan.«

51

E. Hanslick, O muzički lijepom, str. 113.

52

Usp. ibid., str. 88: »Dovoljna mjera razumskoga, koja može po sebi i za sebe ležati u glazbenim tvorevinama forme, temelji se $\mathrm{u}$ izvjesnim primitivnim načelima koja je priroda ugradila u ljudsku organizaciju i vanjske pojave zvuka. Prazakonitost 'harmonijske progresije' nosi u sebi, analogno formi kruga u likovnim umjetnostima, najznačajniju klicu za daljnju obradu i - nažalost gotovo nerazjašnjeno - razjašnjenje različitih glazbenih odnosa.«Usp. također F. W. J. Schelling, Filozofija umjetnosti, str. 131: »[\$ 83.] Forme glazbe forme su vječitih stvari ako one bivaju promatrane $s$ realne strane. (...) Ako nadalje vječite stvari ili ideje s realne strane bivaju očite u svjetskim tijelima, onda su forme glazbe kao forme realno gledanih ideja i forme bitka i života svjetskih tjelesa kao takvih, prema tome glazba nije drugo nego zamijećeni ritam i harmonija vidljivoga univerzuma samog.«

53

Usp. E. Hanslick, Vom Musikalisch-Schönen, str. 65: »Komponiranje je rad duha u produhovljenom materijalu.« 
Međutim, već pojavom glazbenog impresionizma (npr. C. Debussy) dovodi se u pitanje Hanslickov pojam glazbeno lijepog i to zbog uporabe tzv. slobodnog tonaliteta, tj. neposrednog povezivanja akordâ različitih tonaliteta. Nadalje, ne treba posebno naglašavati da pojava atonalne glazbe (A. Schönberg, A. Berg, A. von Webern) svojom uporabom disonanci predstavlja još jedan »težak udarac« za načelo tonaliteta, a »krajnji rezultat« razvoja »moderne« glazbe je odbacivanje bilo kakvoga sadržaja, tj. teme, te okretanje »čistom zvuku« i njegovim »akustičko-glazbenim « mogućnostima (do krajnosti dovedeno npr. kod K. Stockhausena, P. Bouleza, G. Ligetija).

Tako je kompozicija Atmospheres G. Ligetija, kao konkretizacija estetičke ideje o »glazbi zvukovnih boja«, upravo izniman primjer »besadržajne glazbe« u kojoj boja kao »klasično « izražajno sredstvo postaje zapravo materijal, te ujedno i osebujno načelo izgradnje samoga djela. U temeljima suvremene glazbe leži, dakle, potreba za odvajanjem od tonaliteta i centralnog tona harmonije, tj. od klasičnoga melodijsko-harmonijskog sustava. ${ }^{57}$ No, kako primjećuje Ivan Focht,

»... ni poslije treće faze razvitka moderne muzike, 'netematske', nemamo još ništa što bi zamijenilo odbačeni tonalitet, tj. nije pronađen nikakav muzikalno zasnovan princip koji bi rađao nova bića ${ }^{58}$

Drugačije kazano, »modernoj « glazbi - pored toga što poput »klasične« može biti i konstruktivistička i racionalna, i objektivna - prvenstveno nedostaje moment estetičnosti, koji naime i omogućava uspostavu glazbenog bića kao »supstancijalnog «, »duhovno-materijalnog « jedinstva. Pretpostavka je supstancijalnosti »klasične« apsolutne glazbe prisutnost estetskog momenta, dočim poriv za apsolutnošću u »modernoj« glazbi implicira radikalan raskid sa svime što je tonalno, $\mathrm{tj}$. sa svime što nije »čisto« glazbeno.

Ne ulazeći u daljnje strukturne glazbeno-estetičke specifičnosti »moderne« glazbe - koje u konačnici dovode u pitanje i sam »pojam« glazbe, primjerice u slučaju konkretne ili elektroničke glazbe, a čega su svjesni i pojedini suvremeni kompozitori ${ }^{59}$ - valja se prvenstveno zadržati na ontološkom momentu glazbe jer upravo taj moment predstavlja poveznicu između »klasične« i "moderne« glazbe. Imajući u vidu Hanslickov ontologijski stav o glazbi kao zasebnom biću koje »nam se sviđa po sebi, kao arabeska, kao stup, ili kao produkti prirodno lijepog, kao list i cvijet «, ${ }^{60}$ potrebno je ukazati na to da je i kod nekih suvremenih kompozitora, kao što su Stravinski i Schönberg, prisutno ontologijsko shvaćanje glazbe. Iako načela izgradnje u »modernoj « glazbi, kao primjerice dodekafonija u Schönberga, nisu istovjetna Hanslickovim, te usprkos općenitom izostanku »spoznajno-estetskog « momenta u atonalnim glazbenim djelima, može se slobodno reći da su i Schönbergova djela također umjetnički vrijedna glazbena bića. Odmak od tonaliteta i harmonijske funkcionalnosti, kao pretpostavke estetičnosti »klasične« glazbe, Schönberg nadomješta racionalnošću dvanaesttonskog komponiranja, ${ }^{61}$ a to je sukladno i općoj potrebi za racionalnošću unutar fenomena moderne umjetnosti. Schönbergov objektivizam, ${ }^{62} \mathrm{tj}$. okrenutost samoj glazbi i osobito glazbenoj materiji (tonovima), izravno dovodi, uostalom kao i kod Hanslicka, do »ontologizma « (konstruktivizma). Posve je drugo pitanje u kojoj mjeri se glazbeno biće može »voditi« u smjeru negacije estetičko-osjetilnog elementa, a da se pritom ne ugrozi kako mogućnost estetske recepcije glazbe, tako i njezin »duhovno-metafizički« supstancijalitet. Drugim riječima, postavlja se pitanje jesu li, primjerice, atonalna glazbena djela, posebice zbog svoje apstraktnosti, tj. izostanka glazbenog sadržaja, još uopće umjetnička djela u smislu estetske objektiviranosti onog metafizičkog, nadosjetilnog. 
Shodno prethodnim tvrdnjama o »apstraktnosti« atonalne glazbe, nameće nam se i problematika vezana uz moguće estetičko-aksiološko izjednačavanje

54

Usp. E. Hanslick, O muzički lijepom, str. 177: »Ali, glazbeni sadržaj se spašava samo ako se neumoljivo negira postojanje bilo kakvog drugog sadržaja u njoj. Jer, iz onog neodređenog osjećaja na koji se takve sadržine u najboljem slučaju svode ne može se izvesti nikakvo duhovno značenje, ali može iz određenog lijepog oblikovanja tonova kao slobodnog duhovnog stvaranja pomoću produhovljenog materijala.«

55

Usp. ibid., str. 91: »Svaki pojedini glazbeni element (tj. svaki interval, svaka boja zvuka, svaki akord, svaki ritam itd.) ima svoju vlastitu fizionomiju, svoj određeni način djelovanja. Neistraživ je umjetnik, istraživo je umjetničko djelo.»

56

Ibid., str. 100 .

57

Usp. Ivan Focht, »Stravinski nije protiv Haydna«, Izraz 6 (1959), str. 593-594: »Tako, da navedemo samo ono najbitnije, u klasičnoj muzici imamo jednu pregnantno izraženu melodijsku liniju koja je tako organizirana da se dopada - u modernoj iskidano tkivo koje je sve prije nego dopadljivo; tamo muzičku temu i muzičku misao - ovdje atomizirane elemente tonskog materijala od kojih svaki vuče na svoju stranu i ne doprinosi jedinstvenom cjelovitom izrazu (tzv. »punktualni konstruktivizam«); tamo harmoniju i sklad što prija uhu - ovdje same disonance i sudar proturječnih elemenata; ukratko, u klasičnoj muzici imamo tonalitet i centralni ton harmonije, $u$ modernoj atonalnost i disharmoničnost.«

58

Ivan Focht, Moderna umjetnost kao ontološki problem, Institut društvenih nauka, Beograd 1965., str. 78 .

59

Usp. György Ligeti, »Napisana je polifonija - čuti treba harmoniju«, u: Petar Selem (ur.), Novi zvuk, Nakladni zavod Matice hrvatske, Zagreb 1972., str. 79-80: »U djelima Atmospheres i Apparitions napustio sam komponiranje uz pomoć harmonije, odnosno točnije, intervala. Zapravo razorio sam interval dodajući im mnoštvo malih sekundi, koje su posve izgubile svoje harmonijsko obilježje. (...) Neutralizirana harmonija, ili bolje rečeno, eliminirana harmonija svojstvena za Atmospheres i Voluminu, brzo se istrošila. Rekao bih da su oba ova djela na neki način rubni proizvodi određenog stila na koji je jedva moguće nadovezati. Odnosno, moguće je ići dalje, ali vjerujem da se ništa novo ne bi našlo.«

60

E. Hanslick, O muzički lijepom, str. 90.
61

Dodekafonija, odnosno dvanaesttonska tehnika komponiranja, predstavlja Schönbergov odgovor na problem »kaotičnosti« atonalnog komponiranja. Osnovno je naime pravilo atonalne glazbe da iza svakoga tona može slijediti bilo koji drugi ton, te zbog toga i dolazi do oslobađanja disonance i povlačenja harmonije. Schönberg stoga uvodi načelo tonskih nizova ili serija od 12 tonova jednakog trajanja, koje izabire sam kompozitor i potom ih upotrebljava pri izgradnji glazbenog djela. Iz Schönbergova »komponiranja tonovima«, namjesto »komponiranja pomoću tonova«, kao rezultat proizlazi izostanak »glazbenog sadržaja«. Nastankom atonalne glazbe bavio se primjerice i teoretičar glazbe H. Eimert. Vidi Herbert Eimert, Lehrbuch der Zwölftontechnik, 3. Auflage, Breitkopf \& Härtel, Wiesbaden 1954., str. 7: »Iz zbunjujućeg reda, ili nereda, neprestano promjenjivih tonaliteta vodi posljednji korak do isključena dvanaest tonova iz tonske vrste i funkcije. Tonovi su se odvojili od ovog raspadajućeg poretka, te sami postali poredak. Namjesto funkcije interval je postao zakon organiziranja cjelokupne tonske materije. To znači da su kromatski polutonovi postavljeni izvan funkcije i osamostaljeni: kroma postaje "stupnjevana«, od dvanaest polutonova nastaje dvanaest tonova. Ovaj gubitak enharmonijskog - kao osnovni argument jeftine polemike - u povijesnom je pogledu sličan gubitku tonskog roda u 'slobodnom' tonalitetu.« Uz pojavu atonalne glazbe i Stravinski daje zanimljive primjedbe. Vidi Igor Stravinski, Poetika glazbe: u obliku šest predavanja, Algoritam, Zagreb 2009., str. 44: »Već više od stoljeća, glazba opetovano pruža primjere stila u kojem se disonanca emancipirala. Više nije sputana svojom ranijom funkcijom. Postavši zasebnim entitetom, disonanca često niti što anticipira, niti za što priprema. Disonanca nije, dakle, ništa više čimbenik nereda no što je konsonanca garancija sigurnosti. Glazba jučerašnjice i današnjice bez oklijevanja spaja paralelne disonantne akorde, koji time gube svoju funkcionalnu vrijednost a uho posve prirodno prihvaća njihovo supostavljanje.«

62

Usp. Arnold Schönberg, »Odnos prema tekstu«, u: Eva Sedak i Marcel Bačić (ur.), Plava konjica, Hrvatski glazbeni zavod, Zagreb 2009., str. 41-42: »Razmjerno je malo ljudi kadrih na posve muzički način shvatiti ono što muzika ima reći. Uvjerenje da skladba mora pobuditi predodžbe bilo koje vrste, a ako one izostanu znači da se skladba nije razumjela ili da ne vrijedi, toliko je rašireno koliko to mogu biti samo zabluda i banalnost. Ni od jedne se umjetnosti ne zahtijeva nešto slično: dovoljno je djelovanje njezina materijala, pri čemu svakako u drugim umjetnostima ono tvarno, prikazani predmet sam po sebi, ide na ruku ograničenom shvaćanju srednjeg duhovnog staleža. Budući da 
»klasične« $\mathrm{i}$ »moderne« glazbe. Ako je kod »klasične« glazbe i razvidno da je glazbeno lijepo »nerazlučivo jedinstvo« forme i sadržaja, »glazbene ideje« i glazbene materije, onda je takva sveza zapravo neprimjerena u slučaju »moderne « glazbe. Ovdje, međutim, treba imati u vidu da »moderna« glazba ni ne teži za izazivanjem estetske ugode, nego joj je prvenstveno stalo do izgradnje autentičnoga glazbenog bića kao specifične objektivacije glazbenog duha u »tonskoj materiji «. ${ }^{63}$ Povećana potreba za promišljenošću, a naspram izrazite estetičnosti »klasične « glazbe, čini se da ipak ne umanjuje umjetničku vrijednost suvremenih glazbenih djela.

Ali bez obzira na prvenstvo ontologijskog nad estetsko-gnoseologijskim momentom u glazbi, valja ipak navesti i jedno načelo ili zakonitost koja je neophodna kako bi se neka tonska tvorevina uopće i mogla nazvati glazbenim umjetničkim djelom. Dakle, slobodno se može reći da bez načela ponavljanja zapravo i nema glazbe. ${ }^{64}$ Načelo ponavljanja je u Hanslickovoj estetici glazbe vezano uz glazbenu temu, tj. uz oblikovanje melodija, harmonija i ritmova unutar tonalnog sustava, ${ }^{65}$ dočim je u »modernoj « glazbi povezano s ritmiziranjem određene »serije « tonova, odnosno preinakama boje i dinamike. Tako se $\mathrm{u}$ »klasičnoj« glazbi ponavljanje može očitovati kao variranje određene teme, tj. kao kontrastiranje jedne ili više tema (npr. sonata, rondo). Variranje se nadalje može ostvariti i tako da se melodijska linija preinačava uz pomoć ukrasnih tonova, zaostajalica i sl., potom tako da se mijenja mjera, ritam, tempo i harmonija teme (npr. kod Beethovena, Brahmsa), te također i putem tzv. kontrapunktnih simultanih varijacija (npr. kod Bacha). Ponavljanjem, odnosno variranjem i kontrastiranjem pojedinih glazbenih misli ili tema oblikuju se glazbene forme nekog djela. U »klasičnoj« glazbi smisao ponavljanja očituje se naposljetku i u tome što implicira svojevrstan »odjek « u receptivnom estetskom subjektu, odnosno dovodi do reprodukcije melodije u unutrašnjem sluhu, koja već samim time što je na takav način »prepoznata« izaziva osjećaj sviđanja. Ponavljanje stoga, osim što izaziva estetsku ugodu (sviđanje) u subjektu, služi i za izgradnju glazbene ljepote, pa bi se u konačnici moglo ustvrditi da je ponavljanje i svojevrsna »glazbena praforma ${ }^{66}$

$\mathrm{S}$ druge strane, i za metodu variranja tonskih serija pomoću opetovane ritmizacije, što je specifičnost primjerice Schönbergova načina komponiranja, može se reći da je osebujno očitovanje zakonitosti ponavljanja. Međutim, zbog svojevrsne »tehnifikacije« načela ponavljanja, tj. usmjerenosti na akustičko-formalne aspekte tonskog materijala, te izostanka pozitivnog emotivnog sadržaja (estetskog momenta ili lijepog), recepcija atonalnih glazbenih djela izaziva osjećaje otuđenosti, rastrzanosti, odbojnosti itd. ${ }^{67}$ Gubitkom glazbenog sadržaja (teme) atonalna je glazba izgubila i element estetičke neposrednosti. Za razliku od Schönberga, Stravinski ima nešto »prijemčiviji« stil komponiranja jer koristi kako atonalne, tako i tonalne, odnosno politonalne kompozitorske postupke (npr. Posvećenje proljeća). ${ }^{68}$ No i kod Stravinskog prevladava težnja za uspostavom glazbe kao autonomne umjetnosti, tj. za odmakom od sadržajnih asocijacija. ${ }^{69}$ Na pozadini prethodnih razmatranja potrebno je stoga postaviti sljedeće pitanje: Kakva je zapravo »narav« suvremenog bića glazbe, ako tonovi u »modernoj« glazbi ne služe ničemu izvantonskom? Mogući odgovor na postavljeno pitanje relativno je jednostavan. Naime, ontološki se aspekt glazbe - kao ono što povezuje fenomen »klasične« i »moderne« glazbe - u slučaju »klasične« glazbe oslanja na osjetilnost (estetičnost), odnosno estetičku moć tonskog izraza, dok je u slučaju »moderne « glazbe naglasak na onom racionalnom. »Moderna« glazba je umjetničko očitovanje »apsoluta (apsolutiziranog racionaliteta) u elementarnoj čistoći onog zvukovnog. 
Hanslickovo poistovjećivanje glazbeno lijepoga s glazbenim formama, ali i osporavanje nosive teze tzv. osjećajne estetike (Gefühlsästhetik), prema kojoj je istinska svrha glazbe izražavanje ili izazivanje osjećaja pomoću tonova, gledano načelno, predstavlja svojevrsnu pripremu za uspostavu »moderne«

muzici kao takvoj manjka neposredno shvatljiv sadržaj, jedni u njezinu djelovanju traže čistu formalnu ljepotu, drugi poetska zbivanja.«

63

Usp. Theodor Wiesengrund Adorno, Filozofija nove muzike, Nolit, Beograd 1968., str. 6869: »Schönbergova djela su prva djela u kojima stvarno ne može ništa biti drugačije: ona su protokol i konstrukcija u jednom istom. U njima nije preostalo ništa konvencionalno što bi moglo garantirati slobodu igre. Schönberg je i prema igri i prema prividu jednako polemičan. On se okreće protiv muzikanata 'nove stvarnosti' i kolektiva nastrojenog u njihovom duhu kao i protiv romantičnog ornamenta. (...) Negirajući privid i igru muzika tendira spoznaji.« Usp. također I. Focht, Moderna umjetnost kao ontološki problem, str. 94: »To je mislim, centralno pitanje i ja bih na njega odgovorio ovako: on [primitivni čovjek, op. a.] je ostvarivao, pokazivao i objektivirao svoj ili kolektivni duh zajednice u materiji (u kamenu, linijama, bòjama). I upravo to, objektivacija duha u materiji, zajedničko je i njegovoj, i klasičnoj, i modernoj umjetnosti, i umjetnosti okcidenta i umjetnosti orijenta, i egipatskoj, i kineskoj, i grčkoj, i rimskoj, i talijanskoj, i holandskoj, i ruskoj - svakoj umjetnosti.«

64

Usp. Ivan Focht, Istina i biće umjetnosti, Svjetlost, Sarajevo 1959., str. 272: »Svaki muzički stil na svoj osobit način ponavlja muzičku temu ili motiv, osim možda ekspresionistički, budući da izbjegava svaku čvrstu formu. Uzimam kao primjer renesansne madrigale i motete, barokni 'concerto grosso' i kontrapunkt, bečku klasiku, Berliozovu programsku muziku i Wagnerovu muzičku dramu, dakle sve one glavne faze kroz koje je prošla muzička tehnika u svom historijskom razvitku. Ako u svim ovim formama uspijemo otkriti izvjestan način ponavljanja, bit će potvrđena teza da bez ponavljanja nema muzike.«

65

Usp. E. Hanslick, O muzički lijepom, str. 84: »Neiscrpna i neiscrpiva, prije svega dominira melodija kao osnovni oblik glazbene ljepote; hiljadostruko se preobražavajući, obrćući, pojačavajući, harmonija pruža uvijek nove i nove temelje; obje ujedinjene pokreće ritam, ta žila kucavica glazbenog života, a boja ih draž raznovrsnih boja zvuka.«

66

Usp. I. Focht, Istina i biće umjetnosti, str. 279: »Time se objašnjava, za estetiku muzike, vrlo interesantan fenomen, naime da jedan $i$ ist $i$ muzički izraz vrši dvostruku funkciju: jednim svojim svojstvom gradi ljepotu forme, dok drugim svojim svojstvom izražava izvjestan emotivni sadržaj. Tvrdnja da postoji jedinstvo sadržaja i forme ima zato, u odnosu na muzičko djelo, samo ovaj smisao: jedan $\mathrm{i}$ isti muzički izraz vrši ovu dvojaku funkciju.«

67

Usp. T. W. Adorno, Filozofija nove muzike, str. 92-93: »Dvanaesttonska tehnika je stvarno svoja vlastita sudbina. Ona muziku sputava oslobađajući je. Subjekt gospodari muzikom pomoću racionalnog sistema, da bi mu sam podlegao. Kao što se u dvanaesttonskoj tehnici istinsko komponiranje, produktivitet varijacije, pomiče natrag u materijal, tako se dešava sa slobodom kompozitora u cjelini. Dok se ona ostvaruje u vladanju materijalom, postaje jedna odredba materijala koji se subjektu suprotstavlja kao nešto otuđeno i podvrgava ga svojoj sili. Dok je kompozitorova fantazija postigla da materijal potpuno sluša konstruktivnu volju, konstruktivni materijal krnji fantaziju. Od ekspresionističkog subjekta ostaje novoj stvarnosti podčinjenost tehnici.«

68

Usp. I. Stravinski, Poetika glazbe: u obliku šest predavanja, str. 48: »Kad bi se za moju glazbu reklo da je atonalitetna, to bi bilo isto kao da se kaže da sam postao gluh za tonalitetnost. Ali moguće je da dosta dugo ostajem unutar granica strogog poretka tonalitetnosti, a da onda posve svjesno remetim taj poredak radi uspostavljanja novog. U tom slučaju nisam atonalitetan, nego antitonalitetan. «Upravo zbog zadržavanja »pozitivnog« odnosa spram tonalnosti, I. Focht u modernoj glazbi posebno izdvaja Stravinskog. Usp. I. Focht, Moderna umjetnost kao ontološki problem, str. 78-79: »Zato muzici ide danas teško i ići će joj tako sve dok ne pronađe jedan novi sistem komponiranja koji bi počivao na našem sluhu, a ujedno bio u stanju da djelu garantira duhovno jedinstvo cjeline. Koliko mi je poznato, takav sistem još nije pronađen, no ja ne uviđam zašto principijelno ne bi bio moguć. Predradnje su obavljene, kritički je razmotrena čitava muzička prošlost, a ima i nagovještaja i slutnji o tom novom. Tu je najdalje dopro Igor Strawinsky, radeći u jedno doba koje je izrazito nepovoljno za muziku.«

69

Usp. Josip Andreis, Vječni Orfej: uvod u muzičku umjetnost, str. 259: »Taj novi smjer [Neue Sachlichkeit, op. a.], kome je I. Stravinski jedan od prvih predstavnika, napušta programno koncipiranje i negira muzici posebne izražajne mogućnosti. On želi vratiti muzič- 
glazbe kao autonomnoga umjetničkog fenomena, odnosno kao »apsolutne umjetnosti «. ${ }^{70}$ Ono apsolutno u »modernoj« se glazbi očituje i kao »poriv« za »oznanstvenjenjem《 glazbene umjetnosti, odnosno kao odbacivanje »lijepoga« poradi »istinitoga«. Istinitost apsolutnosti »moderne« glazbe sadržana je u mogućnosti samouspostave glazbe onkraj svega izvanglazbenog. Autonomnost »moderne « glazbe izborena je, kako smo prethodno ustanovili, putem ukidanja melodije, $\mathrm{tj}$. radikalnim »oslobođenjem « disonance od konsonance. Ovo je oslobađanje s jedne strane »negacija« onog »estetičko-emotivnog « u glazbi, dok je s druge strane »prijelaz« bića glazbe u područje racionalnosti ili »pojmovnosti«, odnosno u čisti »tonalni« formalizam. 
Tomislav Škrbić

\title{
Hanslick's Understanding of Music
}

\begin{abstract}
Even though Hanslick's aesthetics of music is mostly subsumed under "formalism", it should be said that Hanslick's immanentistic approach to music represents some kind of detachment from so-called aesthetic formalism. Music, according to Hanslick, can neither provoke nor portray emotion, but can only express the dynamic aspect (motion) of emotion. For Hanslick, the "musicalspiritual content", as that which is immanent in the being of music, is in fact a concrete unity of melodic, harmonic and rhythmic forms (the musically beautiful). The development of musical content unfolds simultaneously with the development of the musical forms of a piece. However, Hanslick's linking the musically beautiful with that which is formal "opens" the door to the emergence of "modern" music, in which the final separation between dissonance and consonance occurs. That which ultimately connects "classical" and "modern" music is the ontological aspect of the art of music, which in the case of "classical" music relies on the aesthetic power of tonal expression, while in "modern" music it is primarily directed at rationality. Furthermore, in the "modern" art of music, a piece of music is a peculiar "existential modus" of the rationality of the musical, while in the "classical" art of music, it is but one of the modalities of existence of the being of music.
\end{abstract}

\section{Keywords}

Eduard Hanslick, aesthetics of music, the musically beautiful, formalism, tonality, atonality

koj umjetnosti njezinu punu autonomiju, ne opterećivati je asocijacijama, graditi na trijeznoj linearnosti, isticati ritamske vrijednosti i koncertantne elemente.«

70

Premda Hanslicka ne navodi izrijekom, C. Dahlhaus na jednom mjestu ustvrđuje kako je upravo tzv. »glazbena logika " predstavljala unutrašnju pretpostavku za pojavu »moderne« glazbe. Usp. Carl Dahlhaus, Hans Heinrich Eggebrecht, Sto je glazba?, Hrvatsko društvo glazbenih teoretičara, Zagreb 2009., str. 87-88: »No koliko god je dalekosežno bilo povijesno značenje postklasičke estetike koja je odražavala promjenu stilova, odlučnu je protuinstancu estetici lijepoga - i to već unutar klasičke teorije umjetnosti - ipak tvorila glazbena logika. Znak raspadanja estetike lijepoga zato je nastajanje i upravo epidemijsko širenje 'institucije analize': 'institucije' u smislu društvenoga usmjerenja koje odražava poimanje svijesti i vodi do njegova učvršćivanja. Ako se ljepota neke melodije ne da analizirati (kada je Alban Berg u polemici s Hansom Pfitznerom pokušao racionalno demonstrirati ljepotu Schumannova Sanjarenja, zapravo je analizirao glazbenu logiku), onda je analiza harmonijsko-tonalitetnih i tematsko-motivskih veza i procesa postupak prikladan samoj stvari na koji se doduše u 19. stoljeću, sputanom estetikom lijepog, još uvijek gledalo sa sumnjom, no koji je u 20. stoljeću postao gotovo samorazumljiv način promatranja glazbenih djela za koja se pretpostavlja da postoje zato da bi ih se 'razumjelo'. Glazbu pojmiti u pojmovima - to znači: postati svjestan smisaonih i funkcionalnih veza između dijelova i momenata tonskoga sloga i opravdati ih tako da ih se imenuje...« Kao svojevrsnu potvrdu prethodno iznesenog, ovdje u cijelosti navodimo jedan Hanslickov opis Beethovenove glazbe. Usp. E. Hanslick, O muzički lijepom, str. 63-64: „Slušamo, na primjer, Beethovenovu uvertiru 'Prometeju'. Ono što pažljivo uho prijatelja glazbe u stalnom slijedu u njoj razabire, to je otprilike slijedeće. Tonovi prvog takta, nakon pada u donju kvartu, biserasto se, naglo i tiho uspinju, ponavljajući se točno $\mathrm{u}$ drugom: treći i četvrti takt provode isti tok u još većem opsegu, kapljice istjerane vodoskokom u visinu biserno se rasprskavaju u padu, da bi u naredna četiri takta izvele istu figuru i istu sliku. Pred duhovnim očima slušatelja gradi se dakle u melodiji simetrija između prvog i drugog takta, zatim između ta dva takta $\mathrm{i}$ dva slijedeća, konačno između prva četiri takta kao jednog velikog vala i jednako velika slijedeća četiri korespondentna. Jer bas koji markira ritam označava početak prvih triju taktova jednim udarom, a četvrtog $\mathrm{s}$ dva; isto tako kod slijedeća četiri takta. Dakle, ovdje četvrti takt, nasuprot trima prethodnim, predstavlja različitost koja ponavljanjem u naredna četiri takta postaje simetrična i raduje uho kao dah novosti u staroj ravnoteži. Harmonija u temi ponovno pokazuje korespondenciju jednog velikog i dva mala vala: C-dur trozvuku u prva četiri takta odgovara sekundni akord u petom i šestom, zatim kvint-sekstakord u sedmom i osmom taktu. Ovo uzajamno korespondiranje između melodije, ritma i harmonije proizvodi simetričnu i promjenama bogatu sliku koja bojama zvukova različitih instrumenata i izmjenjivanjem jačine tona dobiva još više svjetla i sjenki. (...) Ovakva analiza pretvara, istina, živo tijelo u kostur i u stanju je da svu ljepotu, ali i svako lažno tumačenje, razori.« 